\title{
The Annual Trend of Solar Radiation Reduction through the Air Plant Green Roof in the South of Thailand
}

\author{
Supasak Noomak, Juntakan Taweekun, and Kuaanan Techato*
}

\begin{abstract}
The using of air plant as green roof has low cost in maintenance as the plant is epiphyte, xerophyte, and growth retardant. The air plant, Tillandsia Cotton Candy is used for this study. The mocked up green roof of $1 \mathrm{x} 1 \mathrm{sq} . \mathrm{m}$ had been used for the testing for one year. The pyranometer was used to measure the solar radiation above the green roof and under the green roof. For 24 hours, the noon time showed the highest different between above and under the green roof. In term of trend, the result showed that the different is not so much from month to month because the solar radiation of Thailand is almost the same. The trend curve of solar radiation of each month above the roof and below the roof had been shown.
\end{abstract}

Keywords - Solar radiation, Green roof, Air Plant.

\section{INTRODUCTION}

$\mathrm{T}$ HAILAND is in the near equator causing the high solar radiation in the form of electromagnetic radiation. The wavelength range of the radiation to the earth includes daylight, UV and infrared with energy $3.854 \times 10^{26} \mathrm{~W} / \mathrm{m}^{2}$ [1]. Anthropogenic higher temperature or global warming is occurred mainly from the emission from energy sector. Therefore, the increasing of green space by growing plants on the roof can help in the reduction of temperature as the concept of green roof. The limitation of the roof to be used for green roof is the weight of soil on the rooftop of the building and its effect e.g. molding, maintenance, watering, and fertilizing. The using of air plant as green roof will be a good solution if the plant can survive from using the dust in the air as fertilizer without demanding from soil and also can using moisture in the air as water. The Tillandsia species clone (Tillandsia recurvifolia Hooker or "Tillandsia Cotton Candy") is a kind of air plant which can be used as green roof in the sense of aforementioned. Its thermal performance will be investigated in this paper if it can drop the solar radiation [2].

\section{The HeAt TRAnSFer through the Deck RoOftop OF THE BUILDING}

Commercial building is a multipurpose building that can be used to benefit all forms such as housing, offices, shops,

Supasak Noomak, Juntakan Taweekun, and Kuaanan Techato* are Faculty of Environmental Management and 2Faculty of Engineering, Prince of Songkla University. restaurants, hotels and etc. The appearance of commercial buildings is either low rise or high rise. The length of the building blocks external air causing the ventilation problems. Including the transmission of heat from the sun to pass through the building envelope is easy to happen because of no shading device. The roof of the commercial building is usually flat concrete exposing to the sun shining every day [3].

\section{AIR PLANT}

This research selected the plant to be used for the green roof in hot and humid climate. The criteria for the selection of genetic are air plants and light weight. The species should be able to be drought-resistant, damp resistant, weather resistant, solar radiation acceptant, free maintenance, leaves all year round, and easy to find in the market. The Tillandsia species clone (Tillandsia recurvifolia Hooker "Tillandsia Cotton Candy" or called T. Cotton Candy in this paper) is suitable to be used in this study. Its leaves surface area is covered by Trichome which can absorb the moisture and nutrients in the air [4], [5].

\section{MethodOLOGY}

The research was conducted at the Faculty of Environmental Management, Prince of Songkla University, Hatyai Campus, Thailand. The area of green roof is 1 square meter of tree will be placed with 10 rows of 10 trees. The solarimeter was installed above and under the green roof. The positions of solarimeter are $50 \mathrm{~cm}$ and $25 \mathrm{~cm}$ under the air plant. The measurement started from 8:00-16.00 hr.

\section{RESULT AND DISCUSSION}

According to the study, the total solar radiation on the green roof (position 1) showed that the range is $899-1,340 \mathrm{~W} / \mathrm{m}^{2}$ and the filtered solar radiation from the sun under the T. Cotton Candy (position 2, Figure 1) is in the range $108-356 \mathrm{~W} / \mathrm{m}^{2}$ (Figure 2). 


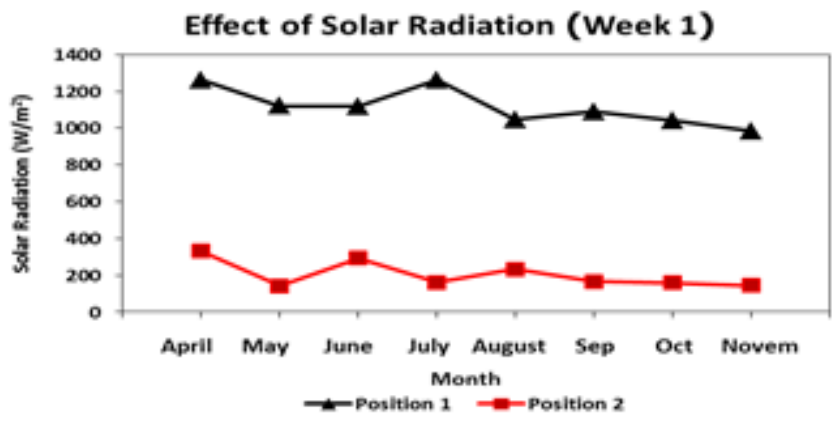

Fig. 1: The intensity of solar radiation emitted and the filtered radiation measured of the first week



Fig. 2: The intensity of solar radiation emitted and the filtered radiation measured of the second week

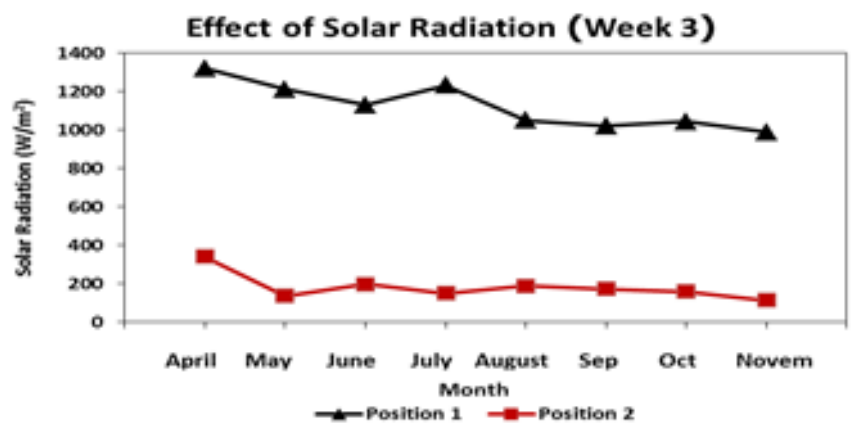

Fig. 3: The intensity of solar radiation emitted and the filtered

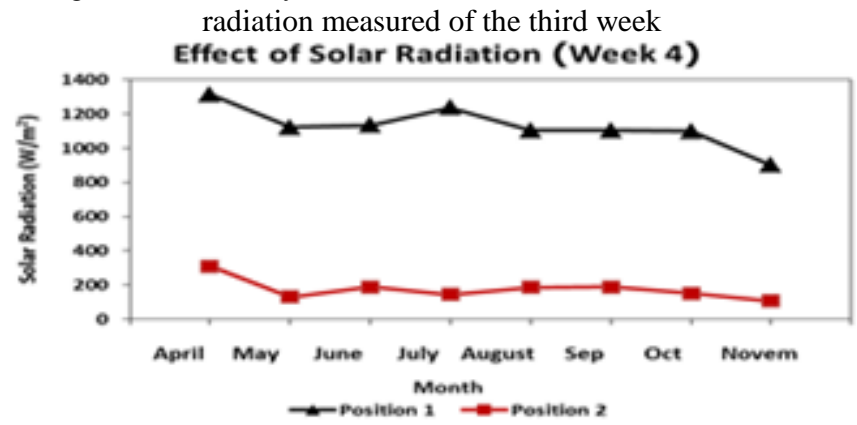

Fig. 4: The intensity of solar radiation emitted and the filtered radiation measured of the fourth week

\section{CONCLUSION}

The experiments in 4 weeks had been compared. The T. Cotton Candy can reduce the solar radiation around 10 times. Even it is air plant which has no soil or media to absorb or reflect the solar radiation but the performance of the solar radiation reduction is good enough to be used as green roof.

\section{REFERENCES}

[1] Lang G, Global warming and German agriculture, "Impact estimation using a restricted profit function," Journal of Environment and Resource Economics, 19: 97-112, 2001. http://dx.doi.org/10.1023/A:1011178931639

[2] Papini, A, G. Tani, P.D. Falco and L. Brighogna, "The ultrastructure of the development of Tillandsia (Bromeliacliaceae) trichome," Flora 205: 94-100, 2010. http://dx.doi.org/10.1016/j.flora.2009.02.001

[3] Regulation No. 55 (2000) "issued under the Building Control Act," Thailand, 1979.

[4] Haslam R, Borland A, Maxwell K and Griffiths H,"Physiological responses of the CAM epiphyte Tillandsiausneoides L. (Bromeliaceae) to variations in light and water supply,"Journal of Plant Physiology 160: 627-634, 2003.

http://dx.doi.org/10.1078/0176-1617-00970

[5] Gueymard, C.A and Myers D.R., "Solar radiation measurement: Progress in radiometer for improved modeling," In V. Badescu. (Ed.) Modeling Solar Radiation at the Earth Surface, Springer, Berlin, 2008. http://dx.doi.org/10.1007/978-3-540-77455-6_1 